\title{
Polysaccharides, Proteins, and Phytoplankton Fragments: Four Chemically Distinct Types of Marine Primary Organic Aerosol Classified by Single Particle Spectromicroscopy
}

\author{
Lelia N. Hawkins and Lynn M. Russell \\ Scripps Institution of Oceanography, University of California, San Diego, La Jolla, CA 92117, USA \\ Correspondence should be addressed to Lynn M. Russell, lmrussell@ucsd.edu
}

Received 5 April 2010; Accepted 14 June 2010

Academic Editor: Markus D. Petters

Copyright ( 2010 L. N. Hawkins and L. M. Russell. This is an open access article distributed under the Creative Commons Attribution License, which permits unrestricted use, distribution, and reproduction in any medium, provided the original work is properly cited.

\begin{abstract}
Carbon-containing aerosol particles collected in the Arctic and southeastern Pacific marine boundary layers show distinct chemical signatures of proteins, calcareous phytoplankton, and two types of polysaccharides in Near-Edge Absorption X-ray Fine Structure (NEXAFS) spectromicroscopy. Arctic samples contained mostly supermicron sea salt cuboids with a polysaccharide-like organic coating. Southeastern Pacific samples contained both continental and marine aerosol types; of the 28 analyzed marine particles, 19 were characterized by sharp alkane and inorganic carbonate peaks in NEXAFS spectra and are identified as fragments of calcareous phytoplankton. Submicron spherical particles with spectral similarities to carbohydrate-like marine sediments were also observed in Pacific samples. In both regions, supermicron amide and alkane-containing particles resembling marine proteinaceous material were observed. These four chemical types provide a framework that incorporates several independent reports of previous marine aerosol observations, showing the diversity of the composition and morphology of ocean-derived primary particles.
\end{abstract}

\section{Introduction}

The transfer of organic components from the ocean surface to marine aerosol through bubble bursting was shown over 40 years ago [1-3]. These components, referred to as "marine primary organic aerosol" or marine POA [4], have been observed to contribute to organic mass in remote and coastal marine locations [3, 5-8]. In some cases, primary components have been observed to compose greater than $70 \%$ of measured submicron OC $[6,7]$. The production of submicron particles from bubble bursting remains a key aspect of the global radiation budget because large particle sources are limited to continental and coastal regions [9]; yet the remote marine atmosphere covers more than half of the earth's surface. In remote regions, marinederived particles have been estimated to account for up to $90 \%$ of cloud condensation nuclei (CCN) [10]. Decreases projected for Arctic sea ice extent in response to climate warming may contribute an additional $40-200 \mathrm{ng} \mathrm{m}^{-3}$ of aerosol organic carbon (OC) by 2100 from a combination of increased surface ocean productivity and increased spatial extent of wave action [11]. This change in OC is significant considering that background concentrations of less than $1 \mu \mathrm{g}$ $\mathrm{m}^{-3}$ are common in the remote MBL $[8,10,12-15]$.

In ocean surface waters, rising bubbles scavenge organic material that is transferred to the atmosphere as the bubble bursts $[1,16,17]$. Much of this scavenged organic material has been classified as "exopolymers," which are mostly composed of polysaccharides [18]. The potential for breaking waves to contribute organic mass to aerosol particles increases with the high concentration of surface active organic compounds and microorganisms enriched in the surface microlayer (SML), relative to the underlying water [19-21]. Observed enrichment factors (EFs) are several orders of magnitude for dissolved and particulate organic carbon (OC) and for specific components like bacteria and viruses. The production of sea spray from bubble bursting results in further enrichment of OC $[8,21,22]$. EFs for organic components in marine aerosol particles have been reported from 5 (viruses and bacteria) to over 100 
(organic carbon) from the SML $[8,21]$. Since the surface ocean is the primary source of marine POA, the types and relative contributions of organic compounds are expected to be similar. Chemical characterization of the SML and surface water has revealed that carbohydrates constitute $80 \%$ of TOC [23], although lipid and protein components have also been observed [21, 24]. Investigations of the composition of airborne marine organic particles have shown multiple lines of evidence for carbohydrates [5, 7, 8, 22, 25-27], amino acids [22, 28], and marine microorganisms [21, 25], confirming that many of the organic components found in the SML and surface ocean are transferred to the marine atmosphere. It is crucial for understanding the role of sea spray aerosol in marine aerosol-cloud interactions that we not only quantify the organic fraction but also characterize its composition, since the hygroscopicity of organic components varies so widely. One important question that remains is how these marine organic components are mixed in airborne particles, since the CCN activity of organic particles can be significantly altered by small amounts of soluble material [29].

To better characterize marine POA in the remote marine boundary layer, aerosol particles were collected during research cruises in the Arctic and southeastern Pacific oceans in local springtime. Single particle X-ray spectromicroscopy was used to separate individual particles into four distinct types of marine POA using organic functional groups, particle morphology, and elemental composition. The findings of this analysis are compared in the context of previous marine POA observations using a variety of analytical techniques.

\section{Methods}

2.1. Sample Collection. Ambient aerosol particles for Scanning Transmission X-ray Microscopy with Near-Edge X-ray Absorption Fine Structure (STXM-NEXAFS) analysis were collected in 2008 as part of the International Chemistry Experiment in the Arctic LOwer Troposphere (ICEALOT) and VAMOS Ocean Cloud Atmosphere Land Study Regional Experiment (VOCALS-REx) research cruises, using nearly identical sample collection techniques. The ICEALOT cruise through the North Atlantic and Arctic Oceans was conducted in March and April 2008 on the UNOLS R/V Knorr to investigate the composition and sources of atmospheric aerosol and gas phase species to the northern polar region. Detailed descriptions of the ICEALOT cruise track, sampled air mass histories, and related aerosol measurements are described in [8] and the associated supplementary material. All ICEALOT single particles presented here were collected north of $63^{\circ} \mathrm{N}$; most particles were collected within the Arctic Circle (north of $66.56^{\circ} \mathrm{N}$ ). In October and November 2008, the NOAA R/V Ronald Brown traveled in the southeastern Pacific Ocean in the region along $20^{\circ} \mathrm{S}$ as part of VOCALS-REx, a multiplatform campaign designed to investigate ocean-atmosphere interface processes and to probe aerosol-cloud interactions in the stratocumulustopped MBL [30]. Details of the VOCALS-REx cruise track, sampled air mass histories, and aerosol chemistry are described in [15]. VOCALS-REx single particle samples were collected along the $20^{\circ} \mathrm{S}$ portion of the cruise track, including both coastal and remote marine locations. For simplicity, all ICEALOT particles will be referred to as "Arctic" and all VOCALS-REx particles will be referred to as "Pacific."

Particles were collected through a shared, isokinetic sampling inlet $18 \mathrm{~m}$ above sea level [31] and impacted onto silicon nitride windows $\left(\mathrm{Si}_{3} \mathrm{~N}_{4}\right.$, Silson, Ltd., Northampton, England) at $1 \mathrm{LPM}$ (providing a $2.5 \mu \mathrm{m} \mathrm{50 \%} \mathrm{efficiency} \mathrm{size}$ cut) using a rotating impactor (Streaker, PIXE International Corp., Tallahassee, FL). This impactor was located in a humidity-controlled enclosure; the relative humidity was below 30\% during ICEALOT and was controlled at 55\% during VOCALS-REx. Windows were sealed and stored frozen until analysis.

\subsection{Analysis}

2.2.1. STXM-NEXAFS. Particles were analyzed on Beamline 5.3.2 at the Advanced Light Source in Lawrence Berkeley National Laboratory (Berkeley, CA) at atmospheric temperature and under dry He (1 atm). Details of STXM-NEXAFS analysis of atmospheric aerosol particles are described in $[32,33]$, and a brief description is provided here. Image scans from 278 to $320 \mathrm{eV}$ (with up to $0.2 \mathrm{eV}$ resolution) of individual particles provide X-ray absorption spectra of the carbon $\mathrm{K}$-edge, with characteristic peaks from various energy transitions of the bound carbon atoms. Organic and inorganic carbon-containing functional groups are identified by their specific absorption energy between 280 and $320 \mathrm{eV}$ (Table 1). Potassium L-edge transitions also occur in this region. Only particles with measurable difference in absorbance between 280 and $292 \mathrm{eV}$ (the carbon edge) are selected for image scans. Energy calibrations were performed within 48 hours of particle analysis using $\mathrm{CO}_{2}$ as the reference material. All necessary adjustments were less than $0.05 \mathrm{eV}$. Absorption spectra from each pixel within the two-dimensional particle image are averaged and normalized following the procedure described in [33]. Spectra normalization entailed subtracting background absorbance $(278-283 \mathrm{eV})$ followed by normalizing to total carbon content $(301-305 \mathrm{eV})$. This normalization provides more uniform spectra for qualitative comparison. Image alignments were performed in Matlab (Mathworks Inc.) using a normalized cross-correlation algorithm implemented in the Matlab image-processing toolbox [33]. An automated algorithm for peak fitting [33] provides relative absorption of aromatic/alkene $\mathrm{R}(\mathrm{C}=\mathrm{C}) \mathrm{R}^{\prime}$, ketone $\mathrm{R}(\mathrm{C}=\mathrm{O}) \mathrm{R}^{\prime}$, alkyl $\mathrm{R}(\mathrm{C}-\mathrm{H})_{n} \mathrm{R}^{\prime}$, carboxylic carbonyl $\mathrm{R}(\mathrm{C}=\mathrm{O}) \mathrm{OH}$, alcohol $\mathrm{R}-\mathrm{COH}$, and carbonate $\mathrm{CO}_{3}{ }^{2-}$ carbon. Spherical-equivalent geometric diameter is used to approximate particle size and is equal to the diameter of a sphere having the same area as the sum of individual pixels with signal above the background level.

Individual particle spectra were clustered using a guided Ward clustering algorithm based on a training set of spectra from the 14 particle classes described in [32]. Following clustering, visual inspection of the resulting classes identified 4 spectra types whose class assignments did not accurately 
TABLE 1: X-ray spectra carbon K-edge, near-edge, and postedge features.

\begin{tabular}{lcc}
\hline Component & Transition & Energy $(\mathrm{eV})$ \\
\hline Aromatic/alkene, & $\mathrm{C} 1 \mathrm{~s}-\pi_{\mathrm{C}=\mathrm{C}}^{*}$ & $284.4-286.4^{a}$ \\
$\mathrm{R}(\mathrm{C}=\mathrm{C}) \mathrm{R}^{\prime}$ & $\mathrm{C} 1 \mathrm{~s}-\pi_{\mathrm{C}=\mathrm{O}}^{*}$ & $286.2-290.9^{a}$ \\
Ketone, $\mathrm{R}(\mathrm{C}=\mathrm{O}) \mathrm{R}^{\prime}$ & $\mathrm{C} 1 \mathrm{~s}-\sigma_{\mathrm{C}-\mathrm{H}}^{*}$ & $287.4-288.5^{a}$ \\
Alkyl, $\mathrm{R}(\mathrm{C}-\mathrm{H})_{n} \mathrm{R}^{\prime}$ & $\mathrm{C} 1 \mathrm{~s}-\pi_{\mathrm{C}=\mathrm{O}}^{*}$ & $288.3 \pm 0.2^{b}$ \\
Amide carbonyl, & $\mathrm{C} 1 \mathrm{~s}-\pi_{\mathrm{C}=\mathrm{O}}^{*}$ & $288.2-288.9$ \\
$\mathrm{R}-\mathrm{NH}(\mathrm{C}=\mathrm{O}) \mathrm{R}^{\prime}$ & $\mathrm{C} 1 \mathrm{~s}-3 \mathrm{p} / \sigma_{\mathrm{C}-\mathrm{OH}}^{*}$ & $289.5 \pm 0.3^{a}$ \\
Carboxylic carbonyl, & $\mathrm{C} 1 \mathrm{~s}-\pi_{\mathrm{C}=\mathrm{O}}^{*}$ & $290.4^{a}$ \\
$\mathrm{R}(\mathrm{C}=\mathrm{O}) \mathrm{OH}$ & $\mathrm{C} 1 \mathrm{~s}-\sigma_{\mathrm{C}-\mathrm{C}}^{*}$ & $290.8-293^{a}$ \\
Alcohol, $\mathrm{R}-\mathrm{COH}$ & & $297.4 \pm 0.2$ \\
Inorganic carbonate, & $\mathrm{L}_{2,3}$ edges & and $299 \pm$ \\
$\mathrm{CO}{ }^{2-}$ & & $0.2^{c}$ \\
Alkyl, $\mathrm{R}(\mathrm{C}-\mathrm{H})_{n} \mathrm{R}^{\prime}$ & & \\
Potassium, $\mathrm{K}$ & &
\end{tabular}

${ }^{a}[34],{ }^{b}[35],{ }^{c}[36]$.

represent their spectral features. These spectra had not been observed in previous STXM-NEXAFS studies of atmospheric particles and therefore were not represented in the 14-class training set. The interpretation of these spectra is described in detail in Section 3.

2.2.2. SEM-EDX. Following STXM-NEXAFS analysis, a subset of analyzed carbon-containing single particles (11 particles) were investigated for elemental composition using Scanning Electron Microscopy with Energy Dispersive Xrays (SEM-EDX) at the Scripps Institution of Oceanography Analytical Facility (La Jolla, CA) using a model FEI Quanta 600 microscope at $10 \mathrm{keV}$. Samples were uncoated and were analyzed under moderate vacuum. All samples showed Si and $\mathrm{N}$ absorption due to the sample substrate. Identified elements include $\mathrm{C}, \mathrm{O}, \mathrm{Ca}, \mathrm{S}, \mathrm{Na}, \mathrm{Mg}$, and $\mathrm{Cl}$.

\section{Results and Discussion}

Figure 1 shows the distribution of analyzed carbonaceous particles in Pacific and Arctic samples categorized by particle-average spectra. Nonmarine particle types include soil dust, combustion, and secondary particles. These particle types have been observed in previous measurements in urban locations (e.g., Mexico City) and areas affected by urban outflow (e.g., offshore China, the Caribbean, and the Pacific Northwest) [32]. Soil dust particles are characterized by carbonate, potassium, and carboxylic acid-containing organic components (Type " $\mathrm{f}$ " in [32]) and are attributed to air masses passing near Santiago and other urban areas along the arid Chilean coast before reaching the ship [15].

Combustion particles show strong aromatic/alkene absorbance at $285 \mathrm{eV}$ and broad alkyl carbon absorption at $292 \mathrm{eV}$ (similar to Type "d" in [32]). With one exception, these particles were submicron, and four out of eight particles were below $300 \mathrm{~nm}$ spherical equivalent diameter.
TABLE 2: Summary of observed marine particle types in southeast Pacific and Arctic samples.

\begin{tabular}{lcc}
\hline \multirow{2}{*}{ Type } & \multicolumn{2}{c}{ No. of Marine Particles } \\
& Pacific & Arctic \\
\hline Polysaccharide & 0 & 43 \\
$\quad$ with carboxylic acid (PsI) & 7 & 0 \\
$\quad$ without carboxylic acid (PsII) & 2 & 4 \\
Protein & 19 & 0 \\
Phytoplankton & 28 & 47 \\
\hline Total &
\end{tabular}

Secondary type particles (type "a" in [32]) are characterized by broad carbon absorption beyond $300 \mathrm{eV}$ and by carboxylic carbonyl absorption at $288.7 \mathrm{eV}$. In previous studies in marine locations, these particles have been the most commonly observed type [32]. In Pacific samples, however, much of the carboxylic acid-containing organic mass is associated with soil dust particles, consistent with measurements reported in [37] of internal mixtures of oxalic and malonic acids with mineral dust.

All organic particles not included in the soil dust, combustion, or secondary particle types were identified as marine origin and fell into four types: carboxylic acidcontaining polysaccharides (Arctic), low-solubility polysaccharides (Pacific), calcareous phytoplankton fragments (Pacific), and proteinaceous material (Arctic and Pacific) (Table 2). Marine particles were observed in both Pacific and Arctic samples; however, most of the particles collected in the Arctic region were supermicron. The features and interpretation of the NEXAFS spectra and STXM morphology of particles in each marine type are discussed in detail in the following sections. In addition, three Pacific particles were identified with carbonate and potassium absorption but without any signatures of organic carbon. Their spectra are very similar to type "E" particles found in ocean sediments in [38], which were identified as marine calcium carbonate. These particles are labeled " $\mathrm{CaCO}_{3}$ " in Figure 1 but are not included below since they lack organic components.

3.1. Carboxylic Acid-Containing Polysaccharides on Sea Salt. Figure 2(a) shows single particle spectra (and category average) for the most commonly observed marine particle type. Spectra in this category have strong carboxylic carbonyl peaks and weak alcohol, carbonate, and potassium peaks. These particles were seen in Arctic samples and compose 43 of the 48 analyzed Arctic particles. Two particles collected at a coastal site in California, which is frequently influenced by marine air masses, also share these features [39]. This particle type is distinct from Type "a" particles in [32] in the stronger contribution of the carboxylic carbonyl peak and the broad alkyl absorption near $293 \mathrm{eV}$. Filter measurements of submicron particles from the Arctic show a large contribution from alcohol $(\mathrm{C}-\mathrm{OH})$ groups to $\mathrm{OM}$ attributed to marine carbohydrate-like compounds [8], consistent with previous chemical characterization of the surface microlayer as $80 \%$ carbohydrate [23] and with exopolymer 


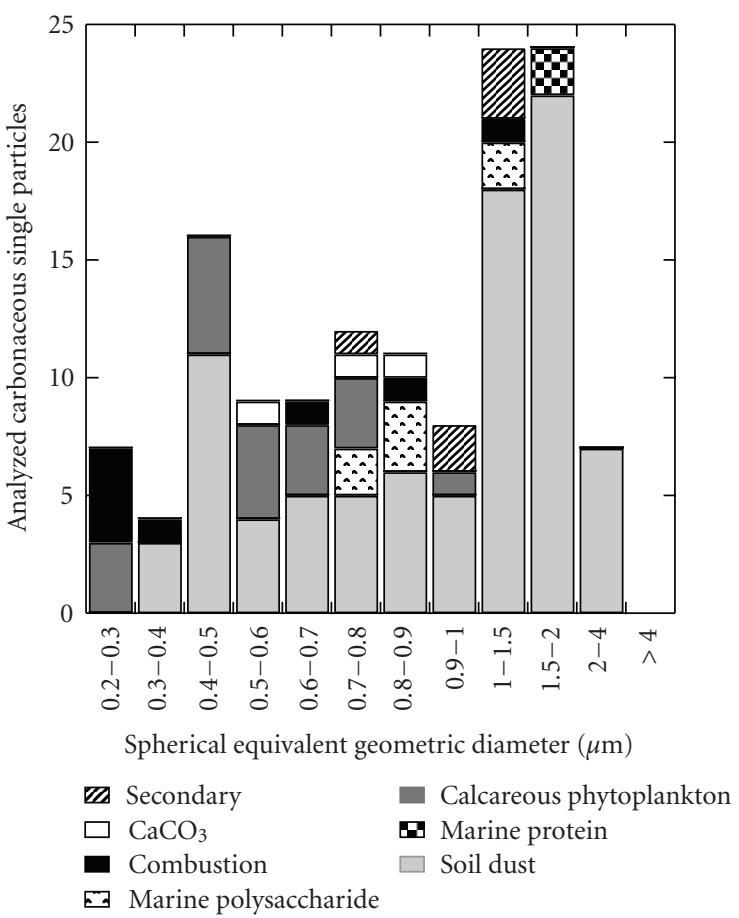

(a)

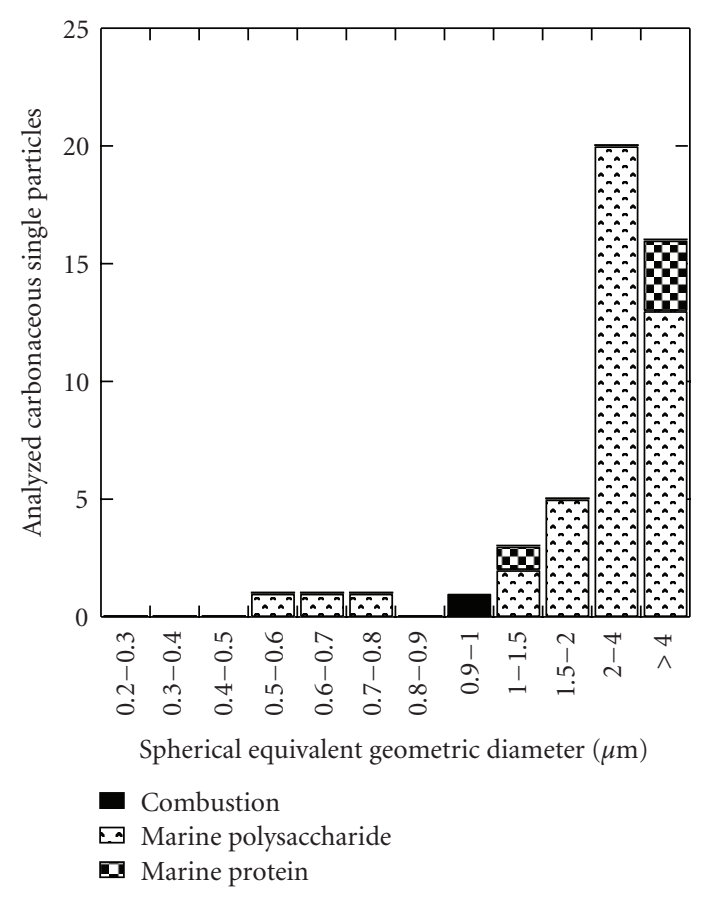

(b)

FIGURE 1: Distribution of the number of analyzed particles from (a) southeastern Pacific and (b) Arctic marine boundary layers. Particles labeled as "marine polysaccharide" in Arctic samples correspond to Figure 2(a) (PsI) while those in southeastern Pacific samples correspond to Figure 2(b) (PsII). Particle frequency for the collected samples is partly a result of sampling bias and does not represent the observed particle size distribution.

secretions (EPSs) repeatedly identified in submicron marine aerosol [7, 25-27]. Just under 90\% of the observed Arctic supermicron particles do not show a significant peak at $289.5 \mathrm{eV}$ (C-OH transition), which is different from most of the reported carbohydrate reference spectra [35]. A fraction of these observed spectra do have a shoulder located near $289.5 \mathrm{eV}$; yet all spectra are dominated by a large peak near $288.7 \mathrm{eV}$ (carboxylic carbonyl). Relative NEXAFS absorption of carboxylic carbonyl and alcohol groups in acid-groupcontaining reference polysaccharides shows a similar trend; for example, muramic acid and alginic acid show stronger carboxylic carbonyl ( $\pi^{*}$ transition) peaks than alcohol ( $\sigma^{*}$ transition) peaks [35] despite the fact that the molar ratio of carboxylic acid to alcohol groups is 0.33 in muramic acid and 0.5 in alginic acid. These compounds are found in bacterial (muramic) and brown algae (alginic) cell walls as structural polysaccharides. Glucuronic acid is another carboxylic acid containing component of polysaccharides that shows strong carboxylic carbonyl absorption $(288.65 \mathrm{eV})$ [35].

Alginic acid is a relevant example for marine POA since the brown algae family includes giant kelp and seaweed found in cold, northern hemisphere oceans [40]. Figure 3 shows the similarities between the average spectrum of particles in this category and an alginic acid reference spectrum [41]. Both spectra show a strong, narrow peak at $288.7 \mathrm{eV}$ and a weaker, broad absorption at $293 \mathrm{eV}$, without any other organic carbon peaks. Carbonate and potassium absorbances in the average carboxylic acid-type spectrum can be attributed to the sea salt associated with these particles. Many of the particles in this type were characterized by inorganic cuboid structures with an uneven, organic coating (Figure 4(a)), which also were absent in the previously observed secondary particles. EDX spectra of four particles from this class are shown in Figure 5 of Russell et al. [8]; observed peaks include $\mathrm{Na}$ and $\mathrm{Cl}$ for all four particles. This small amount of organic relative to crystallized sea salt is consistent with the lower organic enrichment expected for supermicron particles rather than submicron particles. This morphology suggests that the organic components on these particles are more soluble than previously reported polysaccharides, which are generally colloidal spherules not associated with sea salt [25-27]. The association with seawater components is also consistent with the assignment of these particles as carboxylic acidcontaining polysaccharides like alginic acid, since it has a strong tendency to take up water. These particles are referred to as "Type I polysaccharides" or PsI.

3.2. Low-Solubility Polysaccharides. Figure 2(b) shows single particle spectra (and category average) for particles with visible alcohol C-OH absorption $(289.5 \mathrm{eV})$ accompanied by aromatic, ketonic, and carboxylic carbonyl carbon peaks found only in Pacific samples. Here the carboxylic carbonyl absorption is approximately equal to the alcohol carbon absorption. Reference polysaccharides with equivalent peak heights at or near 288.7 (carboxylic carbonyl) and 
TABLE 3: Observed types of marine primary organic aerosol and the suggested biological relevance of specific particle types.

\begin{tabular}{|c|c|c|c|c|}
\hline Location & Method(s) & Particle Size & $\begin{array}{l}\text { Dominant Component(s) } \\
\text { or Spectral Feature }\end{array}$ & Biological Relevance \\
\hline \multicolumn{5}{|c|}{ Polysaccharides } \\
\hline $\operatorname{Arctic}^{a}$ & TEM, & $<100 \mathrm{~nm}$ & Colloidal spherules & EPS gels \\
\hline Various $^{b}$ & $\begin{array}{l}\text { TEM } \\
\text { X-ray backscatter, } \\
\text { and solubility }\end{array}$ & $<1 \mu \mathrm{m}$ & Colloidal spherules & EPS gels \\
\hline $\begin{array}{l}\text { Mediterranean Sea and } \\
\text { Long Island Sound }^{c}\end{array}$ & Alcian blue dye & $1-50 \mu \mathrm{m}$ & Semi-transparent colloids & Polysaccharides \\
\hline W. Pacific ${ }^{d}$ & $\begin{array}{l}\text { TEM, } \\
\text { SEM with X-ray } \\
\text { backscatter, } \\
\text { and solubility }\end{array}$ & $<50 \mathrm{~nm}$ & Colloidal spherules & EPS gels \\
\hline North Atlantic ${ }^{e, *}$ & $\begin{array}{l}\text { HNMR (WSOC and } \\
\text { WIOC) }\end{array}$ & $60-1000 \mathrm{~nm}$ & Hydroxylate aliphatics & Lipopolysaccharides \\
\hline $\operatorname{Arctic}^{f}$ & FTIR spectroscopy & $<1 \mu \mathrm{m}$ & $\begin{array}{l}\text { Lipid-like aliphatics } \\
\text { Organic hydroxyl groups } \\
\text { Alkane groups }\end{array}$ & Polysaccharides \\
\hline SE Pacific ${ }^{g}$ & FTIR spectroscopy & $<1 \mu \mathrm{m}$ & Organic hydroxyl groups & Polysaccharides \\
\hline SE Pacific ${ }^{h}$ & STXM-NEXAFS & $<1 \mu \mathrm{m}$ & Organic hydroxyl groups & Polysaccharides \\
\hline Arctic $^{h}$ & STXM-NEXAFS & $>1 \mu \mathrm{m}$ & Carboxylic acid groups & Polysaccharides \\
\hline \multicolumn{5}{|c|}{ Protein and amino acid compounds } \\
\hline $\operatorname{Arctic}^{i}$ & TEM and Extraction & $>50 \mathrm{~nm}$ & $\begin{array}{l}\text { Hydrophobic organic } \\
\text { aggregates }\end{array}$ & Amino acids \\
\hline Mediterranean Sea and & HPLC and & not provided & Asp, Glu, Ser, Ala & Amino acids \\
\hline Long Island Sound ${ }^{c}$ & Coomassie Blue dye & $1-50 \mu \mathrm{m}$ & Semi-transparent colloids & Proteins \\
\hline Arctic $^{h}$ & STXM-NEXAFS & $>1 \mu \mathrm{m}$ & $\begin{array}{l}\text { Alkane and } \\
\text { amide groups }\end{array}$ & Protein \\
\hline SE Pacific ${ }^{h}$ & STXM-NEXAFS & $>1 \mu \mathrm{m}$ & $\begin{array}{l}\text { Alkane and } \\
\text { amide groups }\end{array}$ & Protein \\
\hline \multicolumn{5}{|c|}{ Micro-organisms and their fragments } \\
\hline $\operatorname{Arctic}^{i}$ & TEM and Extraction & $400 \mathrm{~nm}$ & & Bacteria and diatoms \\
\hline $\operatorname{Arctic}^{a}$ & TEM, & $200-5000 \mathrm{~nm}$ & & $\begin{array}{l}\text { Micro-organisms and } \\
\text { fragments }\end{array}$ \\
\hline \multirow{3}{*}{ W. Pacific ${ }^{d}$} & $\begin{array}{l}\text { X-ray backscatter, } \\
\text { and solubility }\end{array}$ & & & \\
\hline & TEM, & $>400 \mathrm{~nm}$ & $\mathrm{CaCO}_{3}$ & Coral-related \\
\hline & $\begin{array}{l}\text { SEM with X-ray } \\
\text { backscatter, } \\
\text { and solubility }\end{array}$ & 3.7 to $7.5 \mu \mathrm{m}$ & & Bacteria \\
\hline SE Pacific ${ }^{h}$ & STXM-NEXAFS & $<1 \mu \mathrm{m}$ & $\mathrm{CaCO}_{3}$ and alkane groups & $\begin{array}{l}\text { Calcareous phytoplankton } \\
\text { fragments }\end{array}$ \\
\hline \multicolumn{5}{|c|}{ None listed } \\
\hline Tasmania $^{j}$ & PALMS & $>160 \mathrm{~nm}$ & Organic mass fragments & \\
\hline $\operatorname{Arctic}^{k}$ & TEM & $>100 \mathrm{~nm}$ & Organic liquid & Proteins \\
\hline \multirow[t]{3}{*}{ Ireland ${ }^{l}$} & $\mathrm{IC}$ & $<1.5 \mu \mathrm{m}$ & WIOC (not characterized) & \\
\hline & EGA, & & WSOC (aliphatic groups & \\
\hline & $\begin{array}{l}\text { HNMR, } \\
\text { and TOC }\end{array}$ & & $\begin{array}{l}\text { near heteroatoms, HULIS, } \\
\text { and partially oxidized } \\
\text { species }\end{array}$ & \\
\hline
\end{tabular}

*HNMR characterized aerosol was generated in a laboratory setting from collected seawater.

${ }^{a}[25],{ }^{b}[26],{ }^{c}[22],{ }^{d}[27],{ }^{e}[7],{ }^{f}[8],{ }^{g}[15],{ }^{h}$ This work, ${ }^{i}[28],{ }^{j}[14],{ }^{k}[42],{ }^{l}[6]$. 
$289.5 \mathrm{eV}$ (alcohol) include chitin and L-rhamnose [35]. Chitin does not contain any carboxylic carbonyl groups but does contain amide carbonyl groups (monomers are $\mathrm{N}$ acetylglucosamine) which may be responsible for the peak at $288.4 \mathrm{eV}$. Glucosamine is also present in a $1: 1$ ratio with muramic acid monomers in peptidoglycan, which has been shown to be a major constituent of marine dissolved organic matter (DOM) [43]. Therefore, the observed peak in the average alcohol-type spectrum near $288.7 \mathrm{eV}$ could be attributed either to carbonyl in amide groups or to a mixture with carboxylic carbonyl-containing polysaccharides. It is more probable that these particles contain a mixture of structural polysaccharides than isolated compounds, resulting in less pronounced spectral features than the reference spectra. In fact, the most similar spectrum to the category average comes from a sediment sample of marine particulate organic matter (POM, [38]) (Figure 3). [38] used factor analysis to separate different biological compounds in marine $\mathrm{POM}$, and one factor with significant $\mathrm{C}-\mathrm{OH}$ absorption was identified as carbohydrate material. The carbohydratecontaining marine POM shares the aromatic and ketonic carbon absorbances with the spectra of these particles, while reference (pure) structural polysaccharide spectra in [35] do not. Particles of this type are referred to as "Type II polysaccharides" or PsII.

Filter-based FTIR spectroscopic measurements of Pacific submicron particles show a significant contribution from marine OM (from factor analysis) that is most prominent in sampled air masses with low $\mathrm{PM}_{1}$ particle mass $\left(<1 \mu \mathrm{g} \mathrm{m}^{-3}\right)$ and with low radon concentration $\left(<200 \mathrm{mBq} \mathrm{m}^{-3}\right)$, indicating little continental influence [15]. Complementary ion chromatography (IC) measurements show low concentrations of submicron $\mathrm{Na}^{+}\left(<0.1 \mu \mathrm{g} \mathrm{m}^{-3}\right)$ or $\mathrm{Cl}^{-}$ $\left(<0.07 \mu \mathrm{g} \mathrm{m}^{-3}\right)$, which is consistent with the relatively calm seas encountered during the cruise. PsII particles are spherical, with no cuboidal inorganic core (Figure 4(b)), similar to the spherical colloidal structures observed in TEM by [25-27]. The lack of cuboids is consistent with the lower fraction of $\mathrm{Na} / \mathrm{OM}$ expected in submicron particles [44].

3.3. Calcareous Phytoplankton Fragments. Figure 2(c) shows single particle spectra (and category average) for particles with three strong, narrow peaks at 288.1, 290.4, and $292 \mathrm{eV}$ associated with alkyl $\mathrm{R}(\mathrm{C}-\mathrm{H})_{n} \mathrm{R}^{\prime}\left(\pi^{*}\right)$, inorganic carbonate $\mathrm{CO}_{3}{ }^{2-}\left(\pi^{*}\right)$, and alkyl $\mathrm{R}(\mathrm{C}-\mathrm{H})_{n} \mathrm{R}^{\prime}\left(\sigma^{*}\right)$ transitions, respectively. These particles were strictly submicron and found in Pacific samples. A particle with this same characteristic signal was also found in a sample collected at a California coastal site [39]. Compared with all other particle-average spectra, these spectra have much stronger signal-to-noise and have little particle-to-particle variability. These particles also have very little pre-edge absorbance indicating that they are entirely composed of the absorbing (carbonaceous) material, consistent with their strong signal. The narrow alkyl peaks indicate little variation in the neighbors of the absorbing alkyl carbon atoms (e.g., straight-chain alkane compounds) as does the absence of other organic carbon peaks.
The carbonate peak at $290.4 \mathrm{eV}$ is also strong and narrow, indicating that other than the long-chain hydrocarbon compounds, the particle is mostly some form of carbonate. The reference spectrum for $\mathrm{CaCO}_{3}$ is shown in Figure 3 . $\mathrm{CaCO}_{3}$ shares the sharp peak at $290.4 \mathrm{eV}$ and the multiple, broad peaks to the right of $295 \mathrm{eV}$ with the average spectrum. To determine the type of carbonate-based mineral, 6 of the 19 particles in this category were analyzed with SEM-EDX; all particles showed strong $\mathrm{C}, \mathrm{O}$, and $\mathrm{Ca}$ signals while $\mathrm{S}, \mathrm{Na}$, $\mathrm{Mg}$, and $\mathrm{Cl}$ were absent or weak (Figure 5(c)). These particles show a variety of nonspherical shapes. Some particles appear elliptical with sharp points (Figure 4(c)) and others are amorphous. Based on their appearance, the particles resemble small, dust-like fragments. However, their chemical composition is not consistent with aged or processed dust transported to the remote MBL. In addition, long-chain hydrocarbons are not typical of secondary organic aerosol [45]; the absence of S in EDX spectra also makes it unlikely that atmospheric processing is responsible for the majority of organic mass in these particles.

Previous observations of excess $\mathrm{Ca}^{2+}$, relative to sea salt ratios, in marine aerosol have been attributed to fragments of calcium carbonate-producing phytoplankton (coccolithophores) emitted to the atmosphere during bubble bursting [46]. Other possible sources of elevated calcium include EPS, which have been shown to incorporate calcium in gel formation [47]. These single-celled phytoplankton produce delicate, calcium carbonate scales (coccoliths) that continually slough off the organisms during their growth and that are released during predation [48]. These scales are ovalshaped and are typically $500-3000 \mathrm{~nm}$ in length, resulting in fragments that are consistent with the observed size range of these alkane/carbonate particles. Coccolithophores (especially Emiliania huxleyi) are abundant in both highand low-latitude oceans and are responsible for about half of the total oceanic carbonate production [49]. Their blooms are so large and persistent that they can been seen from space in satellite images of ocean color as patches of light green against the dark blue ocean. A recent study measuring whole coccolithophores, detached scales, and calcite fragments in surface waters in the same region as the VOCALS-REx cruise has documented their abundance in the Peru-Chile Upwelling (PCU) and the South Pacific Gyre (SPG) [49]. The measured seawater carbonate particle surface area distribution in their work showed a large peak between 2 and $3 \mu \mathrm{m}$ (corresponding to whole coccoliths with diameters between 1.6 and $2 \mu \mathrm{m}$ ) and a smaller peak at $250 \mathrm{~nm}$ (corresponding to coccolith fragments with diameters around $560 \mathrm{~nm}$ ). This smaller mode is consistent with the size range of observed particles in this category.

In addition to producing a large fraction of oceanic carbonate, coccolithophores are known to produce extremely stable, lipid-like compounds called alkenones $\left(n \mathrm{C}_{37}-\mathrm{C}_{39}\right)$, which contain one ketone group and two or three degrees of unsaturation [50]. Although the exact function of these compounds is unknown, an investigation of alkenones in various organelles and membranes of Emiliania huxleyi has shown that they are predominantly located in the coccolithproducing compartment (CPC) of the cell and are most likely 


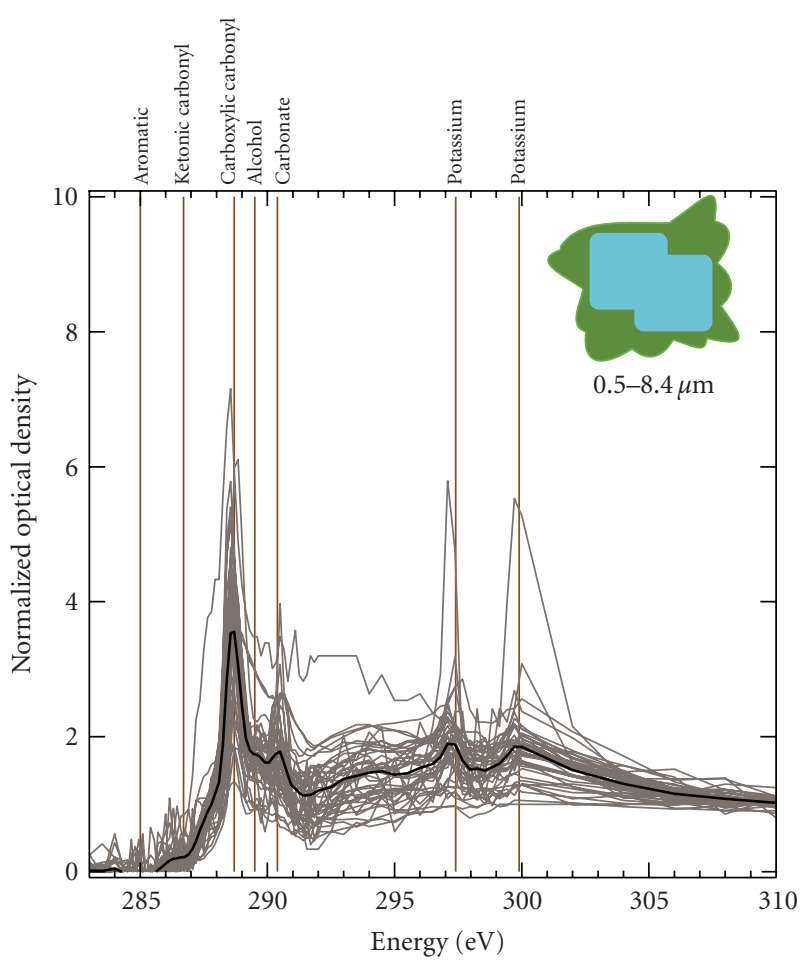

(a)

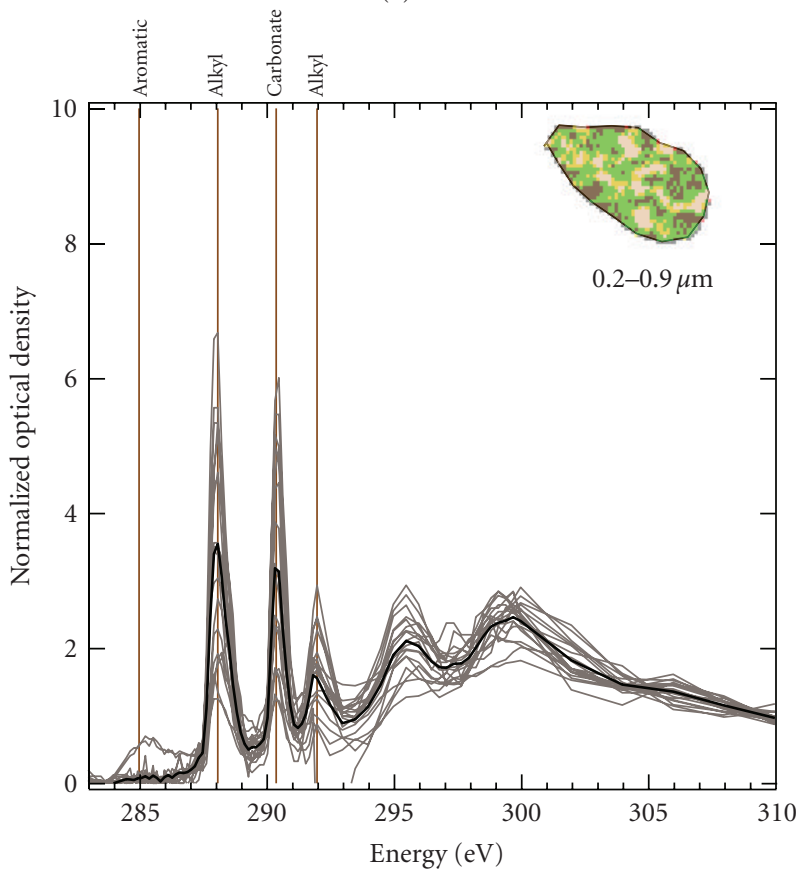

(c)

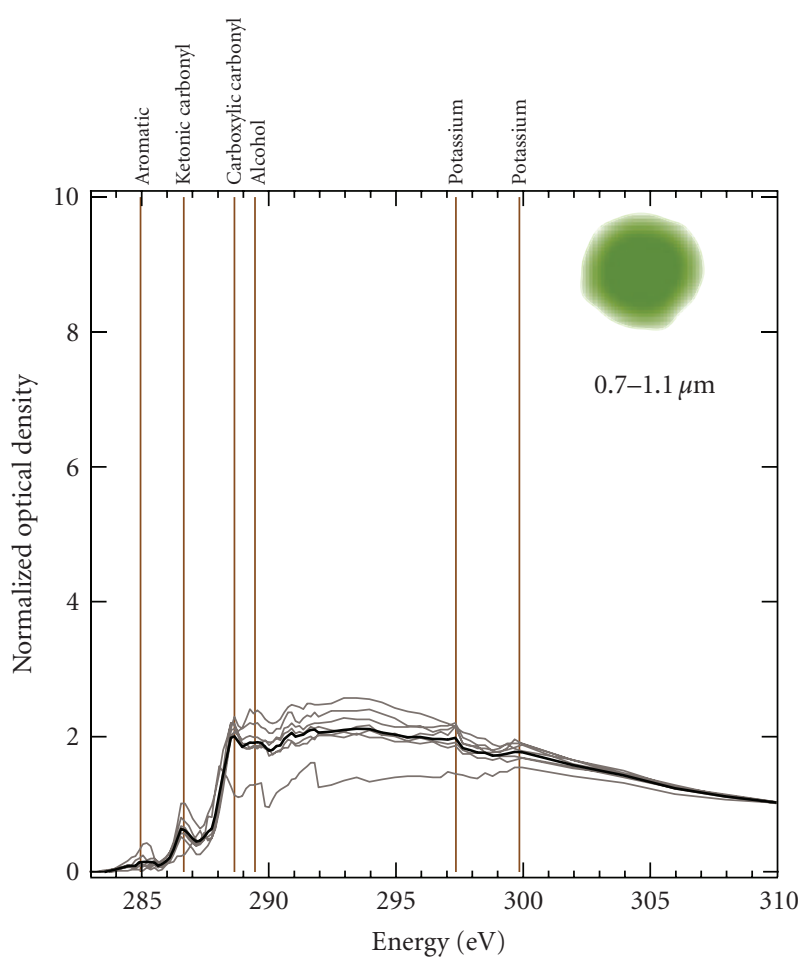

(b)

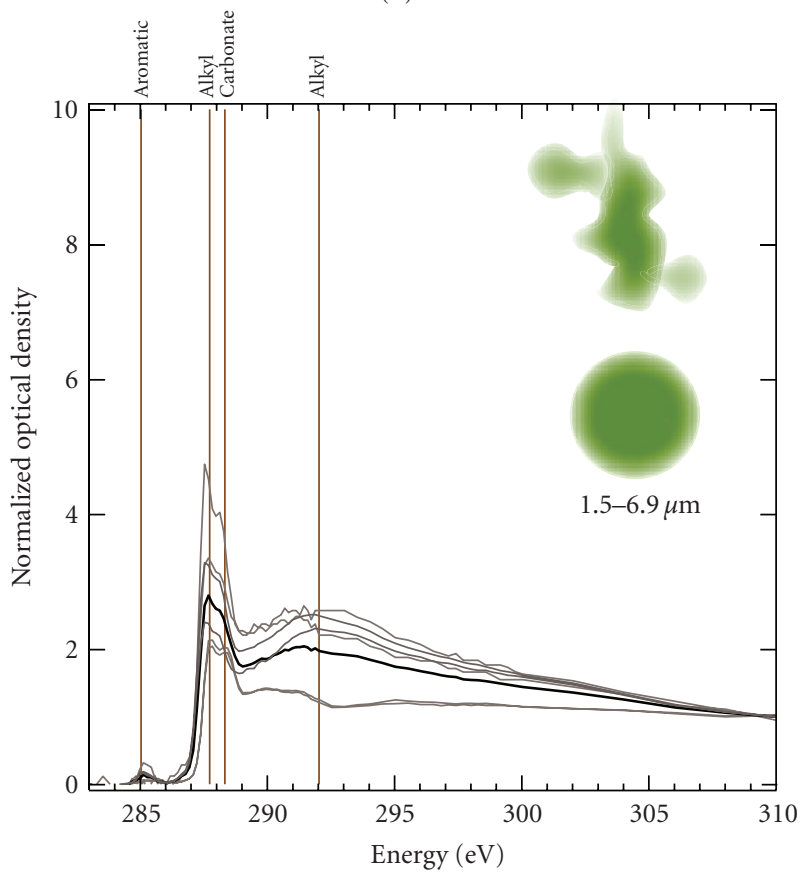

(d)

Figure 2: Individual (grey) and average (black) NEXAFS spectra of the four marine particle types including (a) PsI, (b) PsII, (c) calcareous phytoplankton fragments, and (d) proteinaceous particles. Illustrations in each panel represent commonly observed morphologies associated with each spectra type. The observed size range for each type is shown below the illustrations.

membrane-unbound lipids associated with the function of the CPC [51]. The coproduction of these long-chain alkanes with calcite coccoliths is consistent with the strong, sharp alkyl peaks present in our alkane/carbonate particle spectra and with the absence of other groups, such as carboxylic acids. Coproduction would also result in a similar ratio of the two species (alkane and carbonate) over the particle, rather than separate carbonate and alkane-dominated regions. Figure 5(b) shows the pixel-by-pixel normalized alkane absorption compared with normalized carbonate 


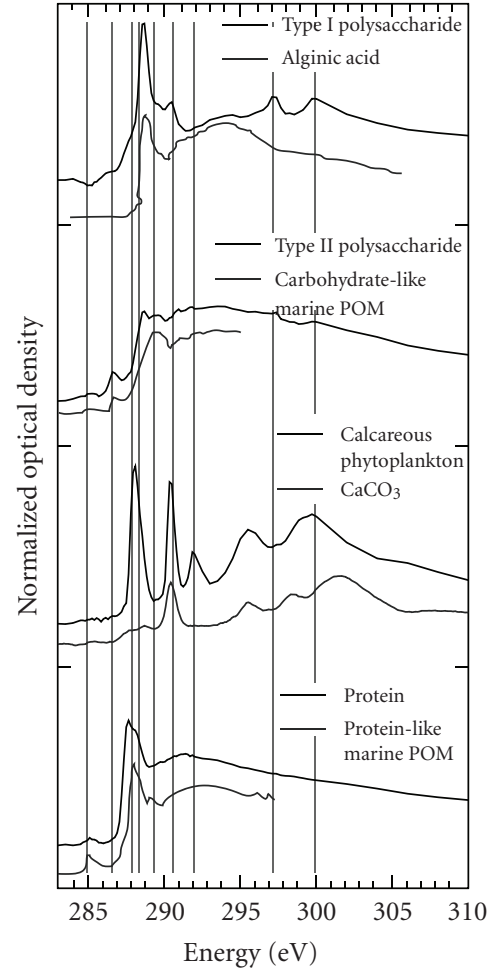

Figure 3: Normalized average spectra for each of the four marine particle types and (below) corresponding reference spectra with similar features. Spectra were reproduced from [41] (alginic acid), [38] (carbohydrate and protein-like marine POM), and http://xrayl.physics.sunysb.edu/ micros/xas/xas.html, unpublished $\left(\mathrm{CaCO}_{3}\right)$. Vertical grey lines mark relevant transitions (from left to right): $285 \mathrm{eV}\left(\mathrm{R}(\mathrm{C}=\mathrm{C}) \mathrm{R}^{\prime}\right), 286.7 \mathrm{eV}\left(\mathrm{R}(\mathrm{C}=\mathrm{O}) \mathrm{R}^{\prime}\right)$, $288.1 \mathrm{eV}\left(\mathrm{R}(\mathrm{C}-\mathrm{H})_{n} \mathrm{R}^{\prime}\right), 288.3 \mathrm{eV}\left(\mathrm{R}-\mathrm{NH}(\mathrm{C}=\mathrm{O}) \mathrm{R}^{\prime}\right), 289.5 \mathrm{eV}(\mathrm{R}-$ $\mathrm{COH}), 290.4 \mathrm{eV}\left(\mathrm{CO}_{3}{ }^{2-}\right), 292 \mathrm{eV}\left(\mathrm{R}(\mathrm{C}-\mathrm{H})_{n} \mathrm{R}^{\prime}\right), 297.4 \mathrm{eV}(\mathrm{K})$, and $299 \mathrm{eV}(\mathrm{K})$.

absorption for each of the 19 alkane/carbonate-type particles. Correlations between these two groups are strong (12 of the 19 particles have $r>0.75$ ). These strong correlations demonstrate the uniformity of the two groups over individual particles, though the relative amounts of alkane and carbonate groups (i.e., the fitted slopes) vary among particles. Given these observations, the alkane/carbonate particles will be referred to as "Calcareous phytoplankton fragments" in the remaining sections.

3.4. Proteinaceous Particles. Figure 2(d) shows single particle spectra (and category average) for particles with aromatic/alkene, alkyl, and amide carbon absorptions at 285, 287.7 , and $288.2 \mathrm{eV}$, respectively. The aromatic/alkene peak at $285 \mathrm{eV}$ has a shoulder at $285.4 \mathrm{eV}$ in all 6 particles indicating the presence of multiple unsaturated carbon environments. These spectra, like the calcareous phytoplankton spectra, have low noise and are quite similar to one another in terms of peak locations, shapes, and relative peak heights. Unlike the other categories, particles with this signature are found in both Arctic and Pacific samples but with slightly different morphologies. The two Pacific particles are spherical and all four of the Arctic particles are loose agglomerations of carbonaceous material (Figure 4(d)). The most unique feature of these spectra is the shoulder at $288.2 \mathrm{eV}$, corresponding to carbonyl carbon in an amide group [34, 35]. Amide groups have also been identified from the $\mathrm{CNH} \sigma^{*}$ transition at $289.5 \mathrm{eV}[34,52]$. Amide groups (known as peptide bonds when found in proteins) are formed from dehydration reactions of the carboxylic acid group of one amino acid monomer and the amine group of another. Therefore, reference spectra for amino acids that have strong carboxyl carbonyl absorption [35] are not representative of bound amino acid monomers in proteins. The broad alkyl absorption near $292 \mathrm{eV}$ indicates that a variety of alkyl carbon environments exist in these particles, contrasting the sharp peak at $292 \mathrm{eV}$ in the calcareous phytoplankton fragments. In addition, the presence of two alkyl carbon peaks and the absence of the carboxylic carbonyl peak indicate that these proteinaceous compounds may be related to lipoproteins that are found in the membranes of chloroplasts. Lipoproteins contain both lipid and protein components and could be responsible for the significant alkyl absorption seen here. Aromatic and alkene groups are found in proteins as well. Phenylalanine, tyrosine, histidine, and tryptophan are all amino acids with aromatic or alkene side groups.

The fourth pair of spectra in Figure 3 show the spectral similarities between the average amide-type particle spectrum and the protein-like component of marine POM identified in [38]. The two spectra share the small shoulder at $285.4 \mathrm{eV}$ and the amide and broad alkyl absorption regions. However, the amide-type average spectrum has more $\pi^{*}$ alkyl absorption $(287.7 \mathrm{eV}$ ) (which is associated with long-chain hydrocarbons such as lipids) than the protein-like marine POM. The lipid component may give these particles more surface active properties and may result in preferential concentration in the surface microlayer. If this is the case, lipid-containing proteinaceous material would be preferentially transferred to the atmosphere during bubble bursting over nonlipid proteinaceous compounds. The particle images in this type, both spherical and agglomerative, show little evidence of sea salt, which is consistent with hydrophobic organic material. In collocated filter measurements of both Pacific and Arctic MBL air masses, primary amines composed $8 \%$ of marine OM (from factor analysis). In fact, primary amine groups have been identified in marine OM factors from all ambient measurements where marine factors were identified [8]. That the Pacific and Arctic proteinaceous POA spectra are indistinguishable reflects the apparent chemical similarity of the protein components in marine POA.

3.5. Reconciling Marine POA Observations. Over 10 years of measurements of marine POA are summarized in Table 3; although the collection encompasses particle properties determined from diverse techniques from TEM-EDX to HNMR, most observations can be assigned to one of three main types: (1) polysaccharides, (2) proteins and amino acids, or (3) microorganisms and their fragments. Figure 6 illustrates the three main types and their surface 


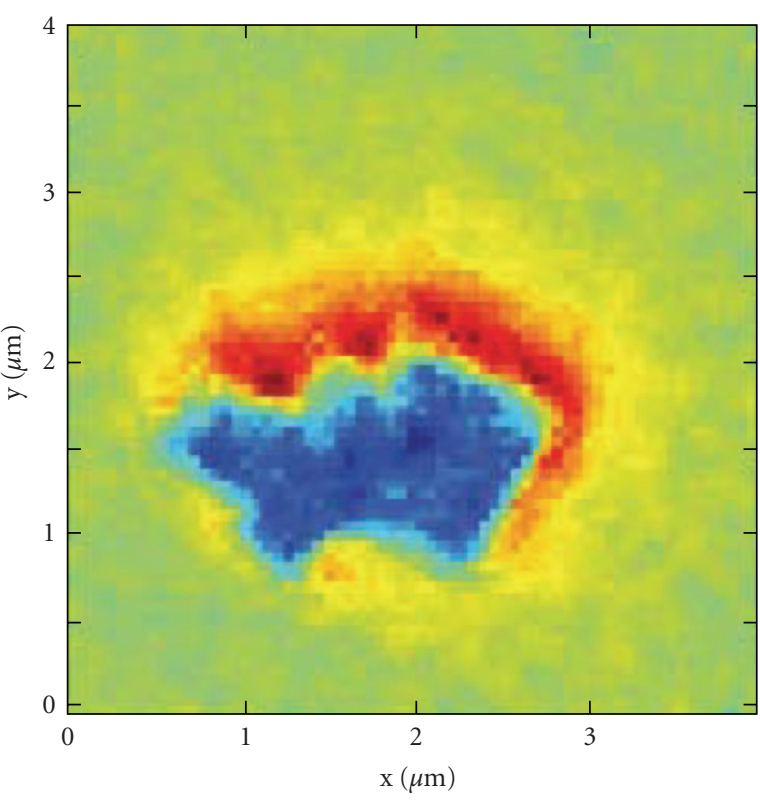

(a)

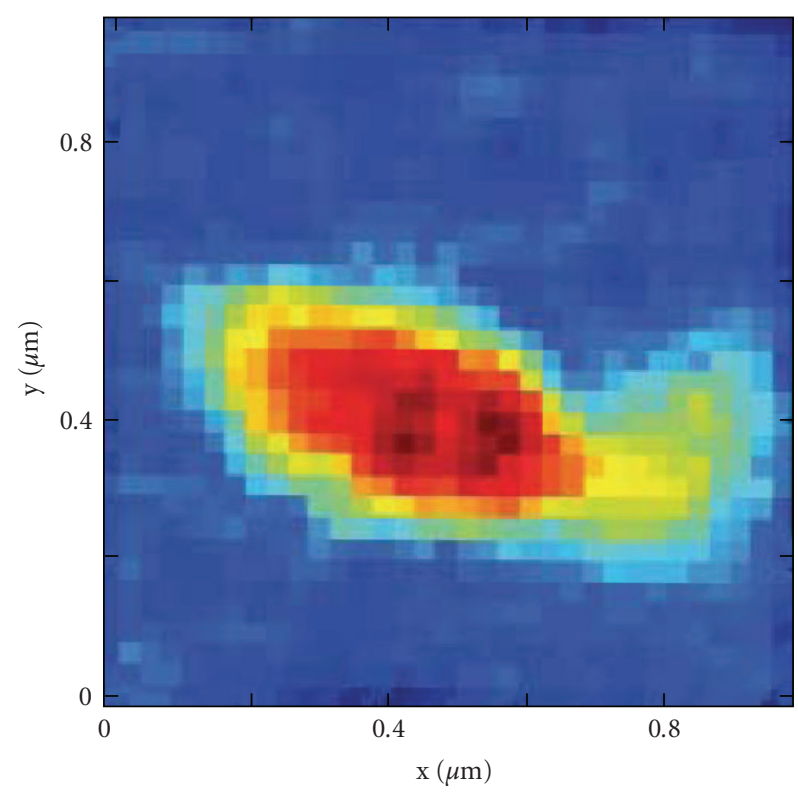

(c)

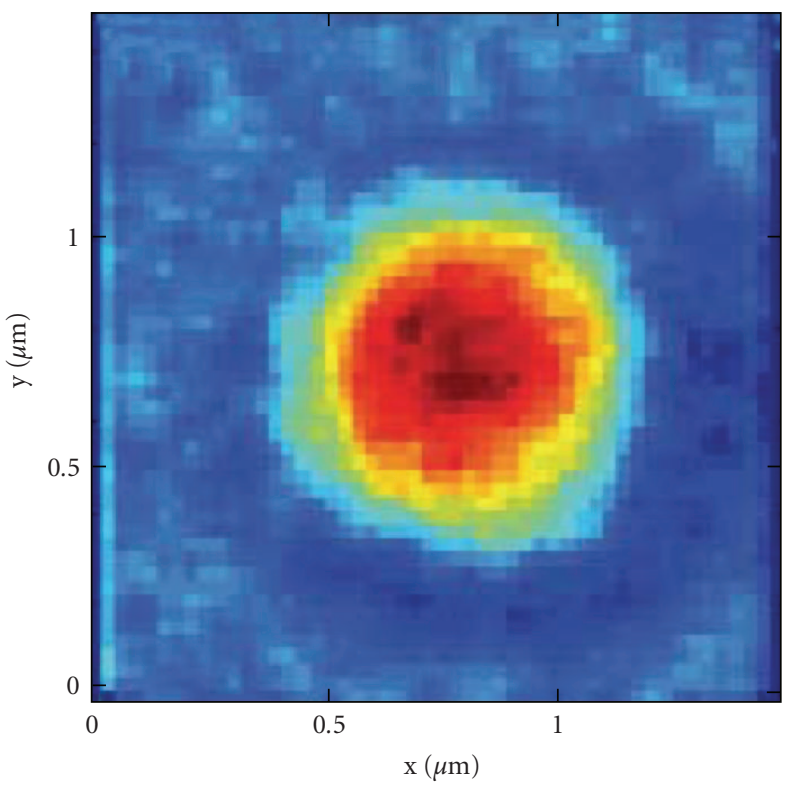

(b)

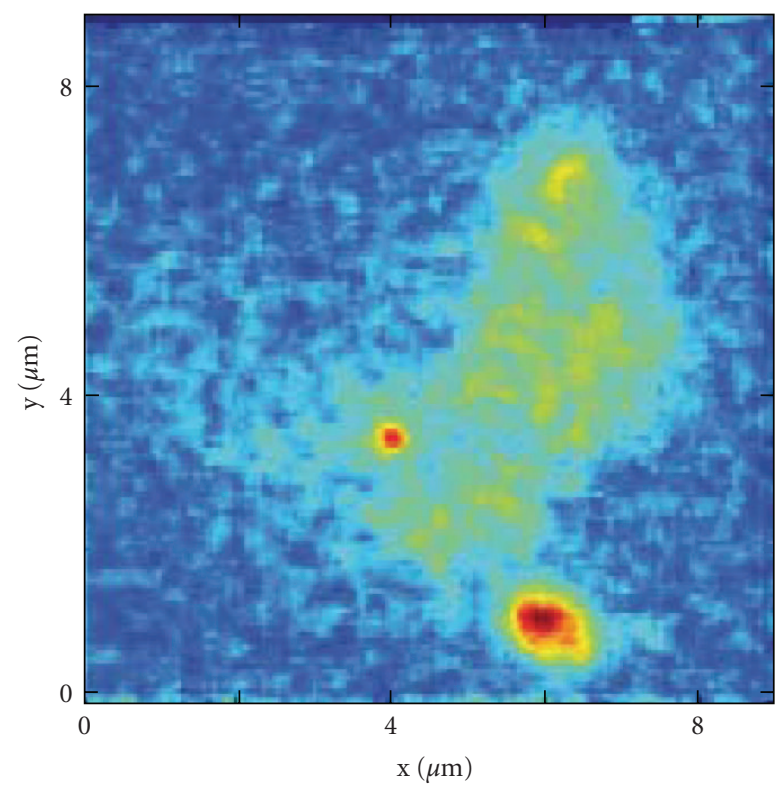

(d)

FIGURE 4: Relative carbon images of representative particles for (a) PsI, (b) PsII, (c) calcareous phytoplankton, and (d) proteinaceous particle types. For each image, the red-blue color scale is relative to individual particle carbon absorption, where red denotes the maximum carbon absorption and blue denotes the minimum.

ocean counterparts using the four types of marine POA particles observed in this study. The chemical characterization of single marine POA particles suggests that biogenic organic components and microorganisms observed in this and previous studies are present as an external mixture including - but not limited to-polysaccharides, proteins, and microorganisms.

Using TEM images of colloidal spherules, X-ray backscatter of elemental components, and tests for solubility, Leck and Bigg $[25,26]$ deduced that the hydrated, heat-resistant, hydrophobic organic substance present in submicron marine aerosol was related to exopolymer secretions (EPSs), which are high molecular weight, hydrated polysaccharides. This finding was consistent with numerous reports of large concentrations of EPS in surface ocean water [18, 47]. The colloidal structure of the hydrophobic particles is also consistent with the observation of gel formation from the marine EPS $[47,53]$. Although the attributes of their measurements of particle shape, size, and solubility were consistent with EPS characteristics, little chemical evidence was available 


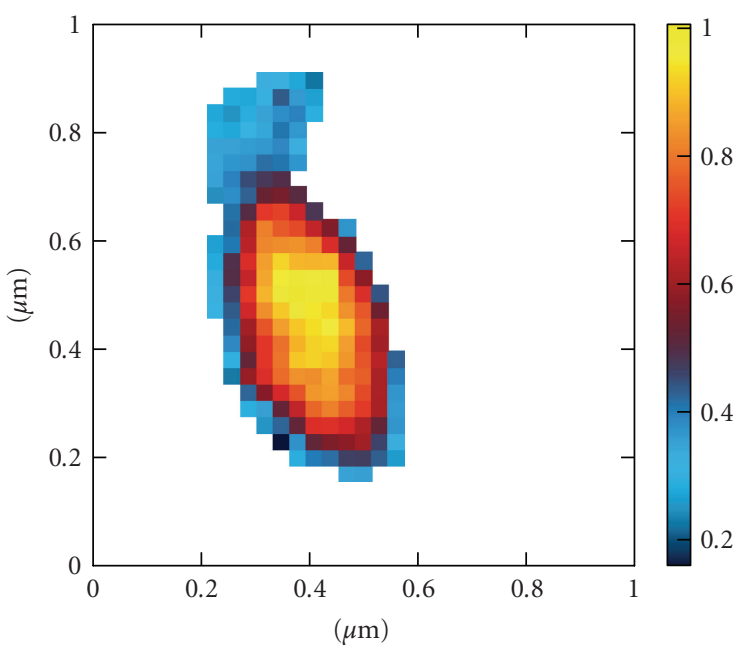

(a)

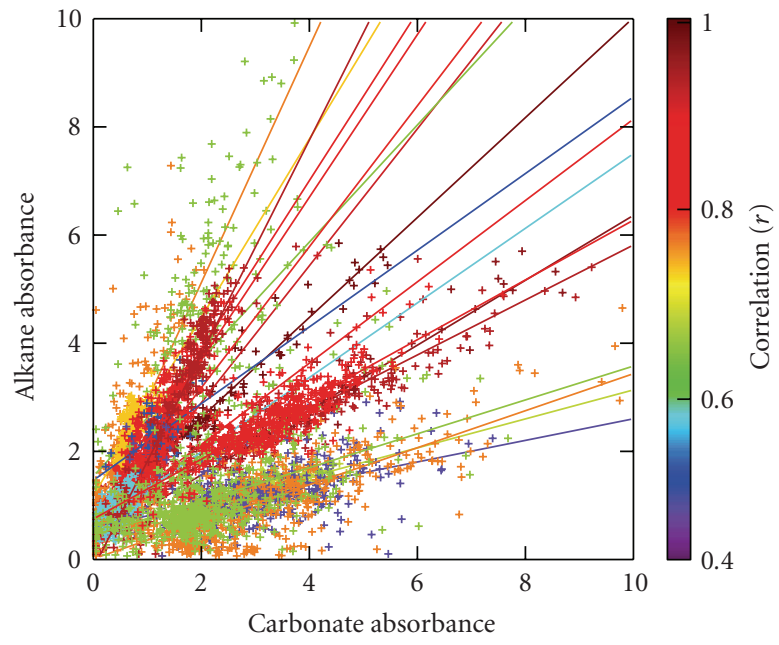

(b)

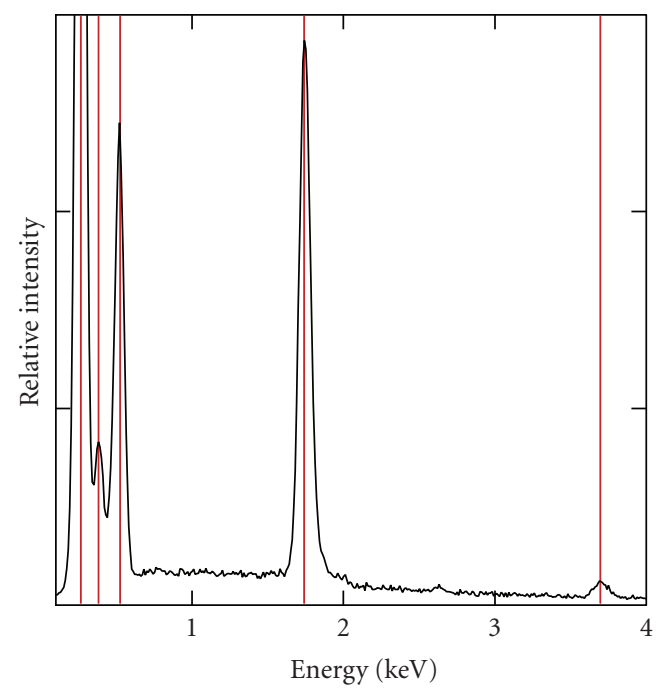

(c)

FIGURE 5: (a) Relative carbon absorbance per pixel from integrated NEXAFS particle-average spectrum for a calcareous phytoplankton fragments. (b) Alkane absorbance compared with carbonate absorbance for pixel-by-pixel fit of NEXAFS spectra of all calcareous phytoplankton type particles. Markers are colored by the correlation coefficient for each least-squares linear regression (one color per particle). (c) EDX spectrum of the same particle at $10 \mathrm{keV}$ accelerating voltage. Vertical red lines mark the C, N, O, Si, and Ca absorbances from left to right. $\mathrm{N}$ and $\mathrm{Si}$ absorbances are from the sample substrate.

to confirm their composition as polysaccharides. Near the same time, ambient marine particles from the Mediterranean and Atlantic were shown to contain polysaccharide-rich gels using Alcian blue dye, a stain sensitive to all types of polysaccharides [22]. EI-MS measurements of marine aerosol in the western Pacific also showed substantial contributions from carbohydrates (i.e., levoglucosan and glucose) partially attributed to organics from the ocean surface [5]. A subsequent HNMR study of laboratory-generated aerosol (using North Atlantic seawater) corroborated the presence of polysaccharide-like organic components in marine POA by reporting aliphatic and hydroxylated functional groups in addition to lipid-like signatures [7]. The authors proposed lipopolysaccharides as a possible explanation for the observed groups. Evidence that polysaccharides accounted for $44-61 \%$ of marine submicron $\mathrm{OM}$ was provided in Russell et al. [8] using FTIR spectroscopy. Their work used the chemical similarity of alcohol $\mathrm{C}-\mathrm{OH}$ groups in ambient marine submicron aerosol with reference FTIR spectra of 11 different polysaccharides (e.g., pectin, glucose, and xylose). That study was the first to report large quantities of specific signatures of polysaccharides associated with sea salt in submicron ambient marine aerosol, consistent with both the physical attributes reported in $[25,27]$ and the chemical signatures of simulated marine aerosol in [7]. Using single particle spectromicroscopy, we have observed that polysaccharide-containing particles make up a majority of the measured carbonaceous single particles in two marine 


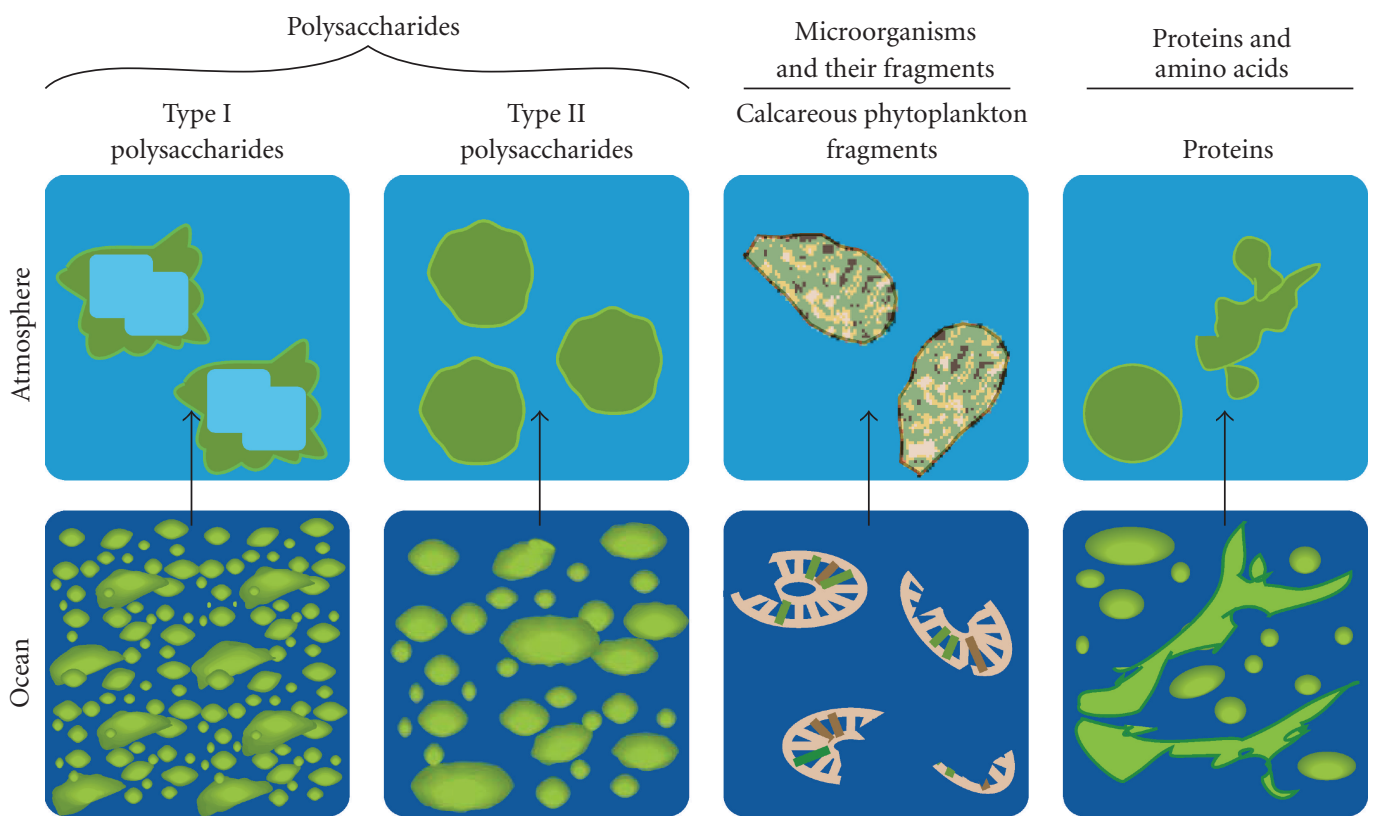

FIGURE 6: Illustration of the four observed marine particle types in the ocean and atmosphere.

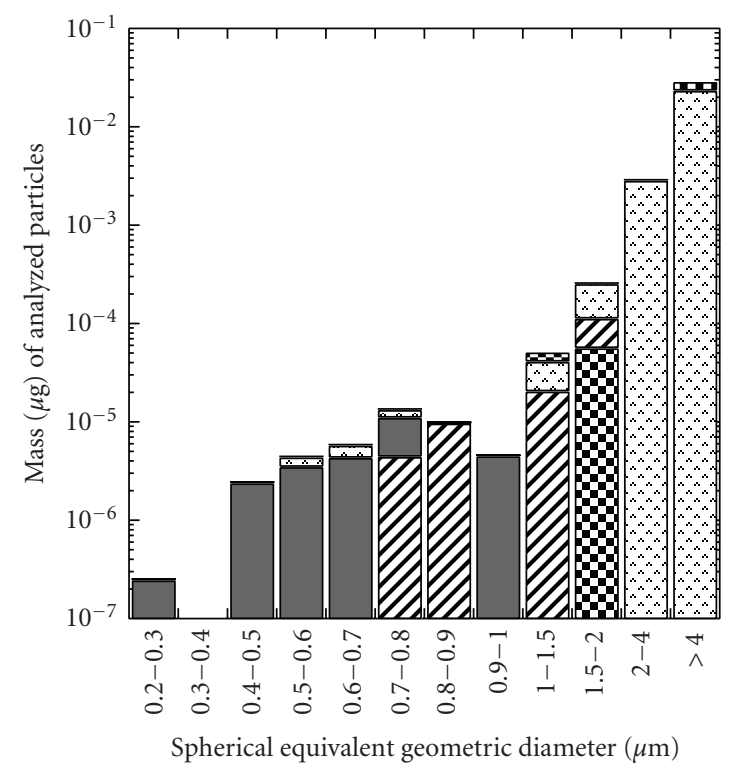

$$
\begin{array}{ll}
\text { Marine protein } & \text { Type I polysaccharide } \\
\text { Calcareous phytoplankton } & \text { Type II polysaccharide }
\end{array}
$$

FIgURE 7: Estimated mass of marine particle types from both Arctic and Pacific samples.

regions. From these single particle measurements we have also estimated the mass distribution of Arctic and Pacific marine particles, using the spherical equivalent diameter approximated for each particle and an average density of $1 \mu \mathrm{g} \mathrm{m}^{-3}$ (for simplicity). Figure 7 shows the combined, approximate mass distribution of Arctic and Pacific marine
POA. Together, Type I and II polysaccharides compose $57 \%$ of measured submicron particle mass (and $83 \%$ of total particle mass), consistent with the observations of [8]. We also show that multiple types of polysaccharides, including water-insoluble compounds resembling chitin, exist in airborne marine particles.

Prior to the discovery of polysaccharides in marine aerosol, TEM analysis of Arctic submicron aerosol particles indicated that the spherical, hydrophobic organic particles could be related to amino acids (i.e., L-methionine) based on the surface active nature of the aerosol particles and on measurements of surface active proteins being scavenged by bubbles in seawater [28]. However, the same properties attributed to proteins in Leck and Bigg [28] could also be attributed to EPS [25-27]. More recently, Kuznetsova et al. [22] used Coomassie blue dye to confirm that some of the colloidal gel-like material surrounding bacteria and virus in Mediterranean and Atlantic marine aerosol samples was indeed proteinaceous. Here we report observations of amidecontaining hydrophobic marine aerosol particles from two distant ocean environments that match the characteristic spectral signatures of proteinaceous marine $\mathrm{POM}$, indicating that protein-like organic compounds also contribute to marine POA in many parts of the marine atmosphere.

Marine microorganisms clearly play a large role in marine aerosol formation and composition. In addition to secreting nonvolatile organic components (e.g., polysaccharides, lipids, and proteins) and emitting gas phase precursors to marine aerosol (e.g., dimethyl sulfide, DMS), they can themselves be lofted to the atmosphere where they can serve as surfaces for heterogeneous reactions and as cloud condensation nuclei [1, 21, 25, 28]. Most observations of airborne microorganisms have reported bacteria or diatom fragments, 
mostly because these particles have distinct shapes easily discernible from other particles in TEM images. Submicron fragments, especially if mixed with gel-like organic material concentrated in the surface microlayer, are extremely difficult to identify based solely on morphology. SEM coupled with EDX can confirm the presence of $\mathrm{C}, \mathrm{O}$, and nutrientaffiliated elements like $\mathrm{N}$ and $\mathrm{P}$ but cannot provide the chemical specificity needed to identify the components of intact cell walls, chloroplasts, or other organelles. For this, X-ray spectromicroscopy is well-suited [38, 41]. Using STXM-NEXAFS we have identified submicron fragments of calcareous phytoplankton (coccolithophores) previously suggested to contribute significant quantities of nss-Ca in MBL aerosol [46]. The unique signature of $\mathrm{CaCO}_{3}$ coupled with straight-chain alkane groups in the average spectra was combined with subparticle resolution spectra-confirming the uniform distribution of the two components- to support the classification of these particles as biological.

\section{Conclusion}

Ambient sub- and supermicron marine aerosol particles were collected in Pacific and Arctic marine boundary layers and subsequently analyzed using single particle STXMNEXAFS, revealing four distinct types of marine POA. Although two-thirds of marine particles were characterized as polysaccharides, important differences exist even among those seemingly similar biogenic compounds, including the association with sea salt and the inferred differences in hygroscopicity. We also report evidence of proteinaceous compounds and the first observation of calcifying phytoplankton in marine POA.

In previous chemical characterizations of marine aerosol, most observations of marine POA show either hydrophobic, polysaccharide-like material or morphologically distinct microorganisms (i.e., bacteria and diatoms). The particles presented here, while consistent with those observations, provide a more detailed, chemically specific picture of marine aerosol that resolves some of the uncertainties associated with previous observations. These observations also confirm that multiple, distinct types of marine particles are emitted to the atmosphere as external mixtures.

\section{Acknowledgments}

This work was supported by NSF Grant ATM-0744636. The authors thank George Flynn for providing the calcium carbonate reference spectrum. The authors would like to acknowledge Satoshi Takahama and Shang Liu for contributing to the analysis of single particles by STXMNEXAFS and David Kilcoyne at Beamline 5.3.2 for technical assistance with beamline operation. They would also like to thank Derek Coffman, James Johnson, Drew Hamilton, and Catherine Hoyle for their assistance in sample collection and analysis as well as the captain and crew of the NOAA R/V Ronald Brown and the UNOLS R/V Knorr for their support in the field.

\section{References}

[1] D. C. Blanchard, "Sea-to-air transport of surface active material," Science, vol. 146, no. 3642, pp. 396-397, 1964.

[2] E. J. Hoffman and R. A. Duce, "Factors influencing the organic carbon content of marine aerosols: a laboratory study," Journal of Geophysical Research, vol. 81, no. 21, pp. 3667-3670, 1976.

[3] R. B. Gagosian, O. C. Zafiriou, E. T. Peltzer, and J. B. Alford, "Lipids in aerosols from the tropical North Pacific: temporal variability," Journal of Geophysical Research, vol. 87, no. 13, pp. 11113-11144, 1982.

[4] M. Kanakidou, J. H. Seinfeld, S. N. Pandis et al., "Organic aerosol and global climate modelling: a review," Atmospheric Chemistry and Physics, vol. 5, no. 4, pp. 1053-1123, 2005.

[5] K. K. Crahan, D. A. Hegg, D. S. Covert et al., "Speciation of organic aerosols in the tropical mid-Pacific and their relationship to light scattering," Journal of the Atmospheric Sciences, vol. 61, no. 21, pp. 2544-2558, 2004.

[6] F. Cavalli, M. C. Facchini, S. Decesari et al., "Advances in characterization of size-resolved organic matter in marine aerosol over the North Atlantic," Journal of Geophysical Research D, vol. 109, no. 24, pp. 1-14, 2004.

[7] M. C. Facchini, M. Rinaldi, S. Decesari et al., "Primary submicron marine aerosol dominated by insoluble organic colloids and aggregates," Geophysical Research Letters, vol. 35, no. 17, p. 5, 2008.

[8] L. M. Russell, L. N. Hawkins, A. A. Frossard, P. K. Quinn, and T. S. Bates, "Carbohydrate-like composition of submicron atmospheric particles and their production from ocean bubble bursting," Proceedings of the National Academy of Sciences of the United States of America, vol. 107, no. 15, pp. 6652-6657, 2010.

[9] C. H. Twohy, M. D. Petters, J. R. Snider et al., "Evaluation of the aerosol indirect effect in marine stratocumulus clouds: droplet number, size, liquid water path, and radiative impact," Journal of Geophysical Research D, vol. 110, no. 8, pp. 1-16, 2005.

[10] A. D. Clarke, S. R. Owens, and J. Zhou, "An ultrafine sea-salt flux from breaking waves: Implications for cloud condensation nuclei in the remote marine atmosphere," Journal of Geophysical Research D, vol. 111, no. 6, pp. 1-2, 2006.

[11] A. Ito and M. Kawamiya, "Potential impact of ocean ecosystem changes due to global warming on marine organic carbon aerosols," Global Biogeochemical Cycles, vol. 24, p. 10, 2010.

[12] D. M. Murphy, J. R. Anderson, P. K. Qulnn et al., "Influence of sea-salt on aerosol radiative properties in the Southern Ocean marine boundary layer," Nature, vol. 392, no. 6671, pp. 62-65, 1998.

[13] P. K. Quinn, D. J. Coffman, V. N. Kapustin, T. S. Bates, and D. S. Covert, "Aerosol optical properties in the marine boundary layer during the First Aerosol Characterization Experiment (ACE 1) and the underlying chemical and physical aerosol properties," Journal of Geophysical Research D, vol. 103, no. 13, pp. 16547-16563, 1998.

[14] A. M. Middlebrook, D. M. Murphy, and D. S. Thomson, "Observations of organic material in individual marine particles at Cape Grim during the First Aerosol Characterization Experiment (ACE 1)," Journal of Geophysical Research D, vol. 103, no. 13, pp. 16475-16483, 1998.

[15] L. N. Hawkins, L. M. Russell, D. S. Covert, P. K. Quinn, and T. S. Bates, "Carboxylic acids, sulfates, and organosulfates in processed continental organic aerosol over the southeast Pacific Ocean during VOCALS-REx 2008," Journal of Geophysical Research, vol. 115, p. 16, 2010. 
[16] D. C. Blanchard, "Bubble scavenging and the water-to-air transfer of organic material in the sea," Advances in Chemistry Series, vol. 145, pp. 360-387, 1975.

[17] R. Tseng, J. T. Viechnicki, R. A. Skop, and J. W. Brown, "Sea-toair transfer of surface-active organic compounds by bursting bubbles," Journal of Geophysical Research, vol. 97, no. 4, pp. 5201-5206, 1992.

[18] A. W. Decho, "Microbial exopolymer secretions in ocean environments-their role (s) in food webs and marine processes," Oceanography and Marine Biology, vol. 28, pp. 73153, 1990.

[19] S. M. Henrichs and P. M. Williams, "Dissolved and particulate amino acids and carbohydrates in the sea surface microlayer," Marine Chemistry, vol. 17, no. 2, pp. 141-163, 1985.

[20] M. Kuznetsova and C. Lee, "Dissolved free and combined amino acids in nearshore seawater, sea surface microlayers and foams: influence of extracellular hydrolysis," Aquatic Sciences, vol. 64, no. 3, pp. 252-268, 2002.

[21] J. Y. Aller, M. R. Kuznetsova, C. J. Jahns, and P. F. Kemp, "The sea surface microlayer as a source of viral and bacterial enrichment in marine aerosols," Journal of Aerosol Science, vol. 36, no. 5-6, pp. 801-812, 2005.

[22] M. Kuznetsova, C. Lee, and J. Aller, "Characterization of the proteinaceous matter in marine aerosols," Marine Chemistry, vol. 96, no. 3-4, pp. 359-377, 2005.

[23] L. I. Aluwihare, D. J. Repeta, and R. F. Chen, "A major biopolymeric component to dissolved organic carbon in surface sea water," Nature, vol. 387, no. 6629, pp. 166-169, 1997.

[24] K. Larsson, G. Odham, and A. Södergren, "On lipid surface films on the sea. I. A simple method for sampling and studies of composition," Marine Chemistry, vol. 2, no. 1, pp. 49-57, 1974.

[25] C. Leck and E. K. Bigg, "Biogenic particles in the surface microlayer and overlaying atmosphere in the central Arctic Ocean during summer," Tellus B, vol. 57, no. 4, pp. 305-316, 2005.

[26] C. Leck and E. K. Bigg, "Source and evolution of the marine aerosol-a new perspective," Geophysical Research Letters, vol. 32, no. 19, pp. 1-4, 2005.

[27] C. Leck and E. K. Bigg, "Comparison of sources and nature of the tropical aerosol with the summer high Arctic aerosol," Tellus. Series B, vol. 60, no. 1, pp. 118-126, 2008.

[28] C. Leek and E. Keith Bigg, "Aerosol production over remote marine areas-a new route," Geophysical Research Letters, vol. 26, no. 23, pp. 3577-3580, 1999.

[29] G. C. Roberts, P. Artaxo, J. Zhou, E. Swietlicki, and M. O. Andreae, "Sensitivity of CCN spectra on chemical and physical properties of aerosol: a case study from the Amazon Basin," Journal of Geophysical Research D, vol. 107, no. 20, pp. 1-37, 2002.

[30] R. Wood, C. Bretherton, B. Huebert, C. R. Mechoso, and R. Weller, "VOCALS SouthEast Pacific Regional Experiment (REx)," Scientific program overview, 2006, http://www.usclivar .org/science_status/VOCALS_SPO_Revised_Complete.pdf.

[31] T. S. Bates, P. K. Quinn, and D. Coffman, "Boundary layer aerosol chemistry during TexAQS/GoMACCS 2006: insights into aerosol sources and transformation processes," Journal of Geophysical Research, vol. 113, p. 18, 2008.

[32] S. Takahama, S. Gilardoni, L. M. Russell, and A. L. D. Kilcoyne, "Classification of multiple types of organic carbon composition in atmospheric particles by scanning transmission X-ray microscopy analysis," Atmospheric Environment, vol. 41, no. 40, pp. 9435-9451, 2007.
[33] S. Takahama, S. Liu, and L. M. Russell, "Coatings and clusters of carboxylic acids in carbon-containing atmospheric particles from spectromicroscopy and their implications for cloudnucleating and optical properties," Journal of Geophysical Research, vol. 115, 2010.

[34] S. C. B. Myneni, "Soft X-ray spectroscopy and spectromicroscopy studies of organic molecules in the environment," Reviews in Mineralogy and Geochemistry, vol. 49, no. 1, pp. 485-579, 2002.

[35] D. Solomon, J. Lehmann, J. Kinyangi et al., "Carbon (1s) NEXAFS spectroscopy of biogeochemically relevant reference organic compounds," Soil Science Society of America Journal, vol. 73, no. 6, pp. 1817-1830, 2009.

[36] T. H. Yoon, K. Benzerara, S. Ahn, R. G. Luthy, T. Tyliszczak, and G. E. Brown Jr., "Nanometer-scale chemical heterogeneities of black carbon materials and their impacts on PCB sorption properties: soft X-ray spectromicroscopy study," Environmental Science and Technology, vol. 40, no. 19, pp. 5923-5929, 2006.

[37] R. C. Sullivan and K. A. Prather, "Investigations of the diurnal cycle and mixing state of oxalic acid in individual particles in Asian aerosol outflow," Environmental Science and Technology, vol. 41, no. 23, pp. 8062-8069, 2007.

[38] J. A. Brandes, C. Lee, S. Wakeham et al., "Examining marine particulate organic matter at sub-micron scales using scanning transmission X-ray microscopy and carbon X-ray absorption near edge structure spectroscopy," Marine Chemistry, vol. 92, no. 1-4, pp. 107-121, 2004.

[39] S. Liu, D. A. Day, and L. M. Russell, "Afternoon increase of oxygenated organic functional groups at a coastal site in Southern California," in preparation.

[40] C. van den Hoek, "Phytogeographic distribution groups of benthic marine algae in the North Atlantic Ocean. A review of experimental evidence from life history studies," Helgoland Marine Research, vol. 35, no. 2, pp. 153-214, 1982.

[41] J. R. Lawrence, G. D. W. Swerhone, G. G. Leppard et al., "Scanning transmission X-ray, laser scanning, and transmission electron microscopy mapping of the exopolymeric matrix of microbial biofilms," Applied and Environmental Microbiology, vol. 69, no. 9, pp. 5543-5554, 2003.

[42] E. K. Bigg and C. Leck, "Properties of the aerosol over the central Arctic Ocean," Journal of Geophysical Research D, vol. 106, no. 23, pp. 32101-32109, 2001.

[43] R. Benner and K. Kaiser, "Abundance of amino sugars and peptidoglycan in marine particulate and dissolved organic matter," Limnology and Oceanography, vol. 48, no. 1, pp. 118128, 2003.

[44] C. Oppo, S. Bellandi, N. Degli Innocenti et al., "Surfactant components of marine organic matter as agents for biogeochemical fractionation and pollutant transport via marine aerosols," Marine Chemistry, vol. 63, no. 3-4, pp. 235-253, 1999.

[45] Q. Zhang, J. L. Jimenez, M. R. Canagaratna et al., "Ubiquity and dominance of oxygenated species in organic aerosols in anthropogenically-influenced Northern Hemisphere midlatitudes," Geophysical Research Letters, vol. 34, no. 13, p. 6, 2007.

[46] H. Sievering, J. Cainey, M. Harvey, J. McGregor, S. Nichol, and P. Quinn, "Aerosol non-sea-salt sulfate in the remote marine boundary layer under clear-sky and normal cloudiness conditions: ocean-derived biogenic alkalinity enhances sea-salt sulfate production by ozone oxidation," Journal of Geophysical Research D, vol. 109, no. 19, pp. 1-12, 2004.

[47] P. Verdugo, A. L. Alldredge, F. Azam, D. L. Kirchman, U. Passow, and P. H. Santschi, "The oceanic gel phase: a bridge in 
the DOM-POM continuum," Marine Chemistry, vol. 92, no. $1-4$, pp. 67-85, 2004.

[48] R. H. M. Godoi, K. Aerts, J. Harlay et al., "Organic surface coating on Coccolithophores-Emiliania huxleyi: its determination and implication in the marine carbon cycle," Microchemical Journal, vol. 91, no. 2, pp. 266-271, 2009.

[49] L. Beaufort, M. Couapel, N. Buchet, H. Claustre, and C. Goyet, "Calcite production by coccolithophores in the south east Pacific Ocean," Biogeosciences, vol. 5, no. 4, pp. 1101-1117, 2008.

[50] R. W. Jordan and A. Kleijne, "A classification system for living coccolithophores," in Coccolithophores, pp. 83-105, Cambridge University Press, Cambridge, UK, 1994.

[51] K. Sawada and Y. Shiraiwa, "Alkenone and alkenoic acid compositions of the membrane fractions of Emiliania huxleyi," Phytochemistry, vol. 65, no. 9, pp. 1299-1307, 2004.

[52] L. M. Russell, S. F. Maria, and S. C. B. Myneni, "Mapping organic coatings on atmospheric particles," Geophysical Research Letters, vol. 29, no. 16, p. 4, 2002.

[53] W.-C. Chin, M. V. Orellana, and P. Verdugo, "Spontaneous assembly of marine dissolved organic matter into polymer gels," Nature, vol. 391, no. 6667, pp. 568-572, 1998. 

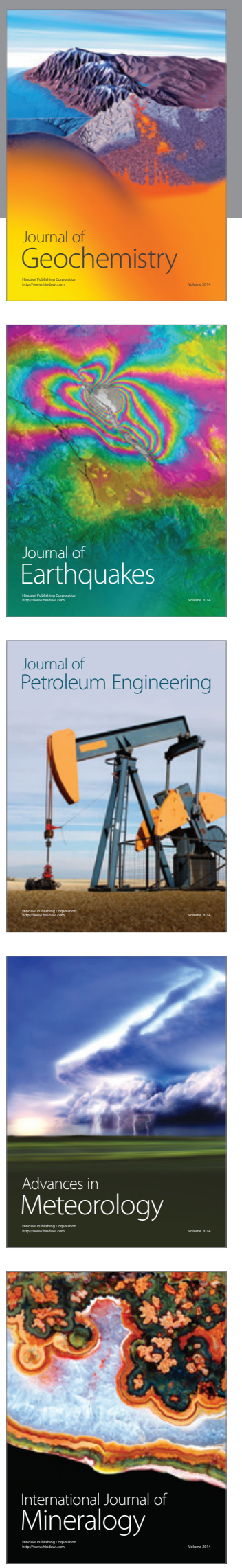
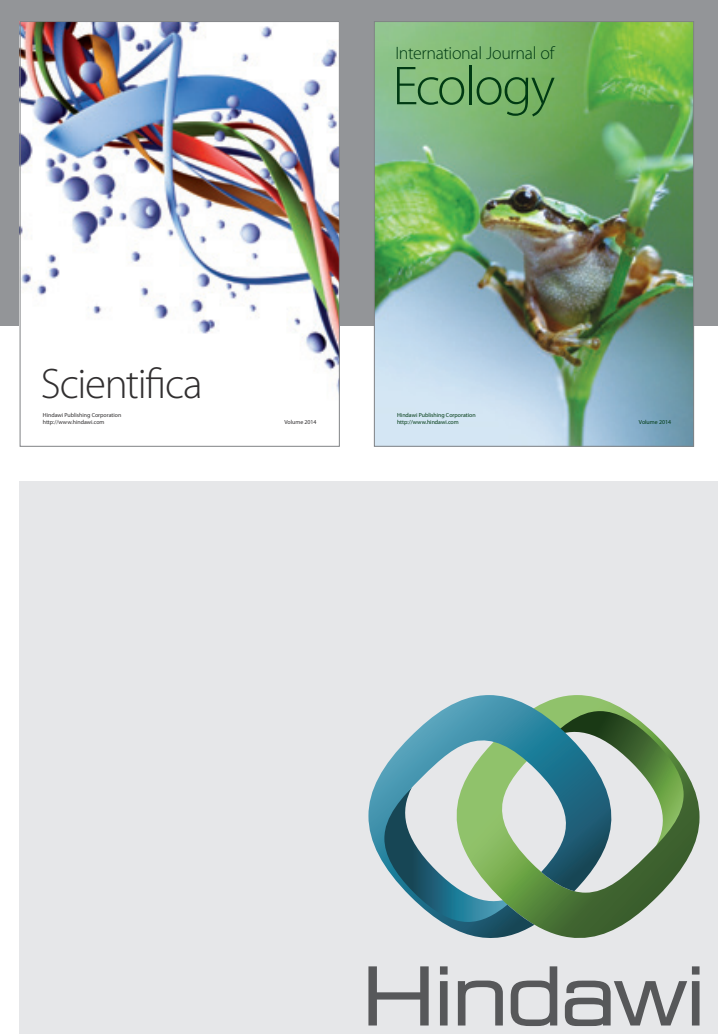

Submit your manuscripts at http://www.hindawi.com
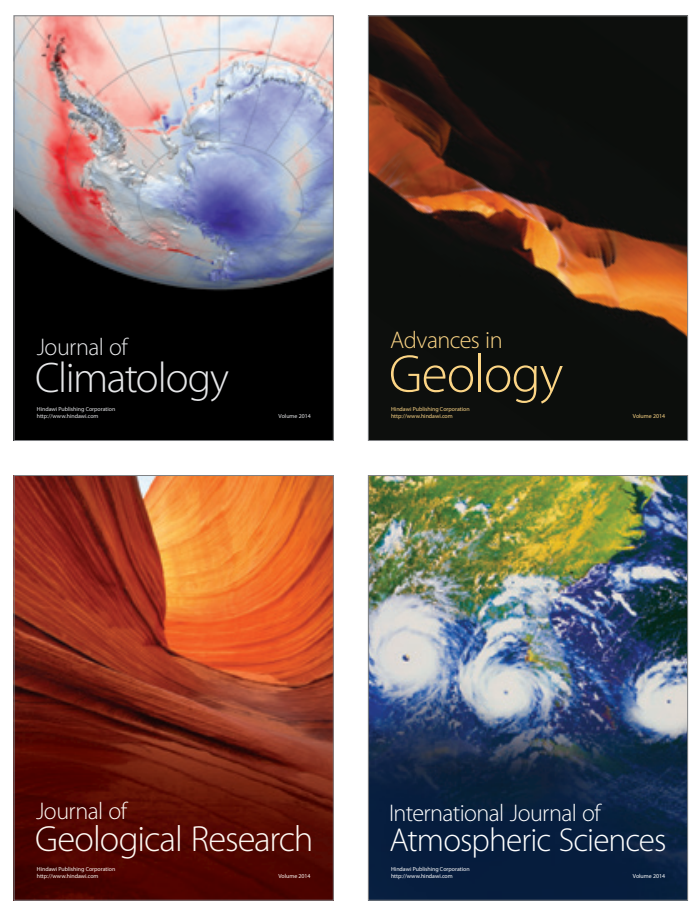
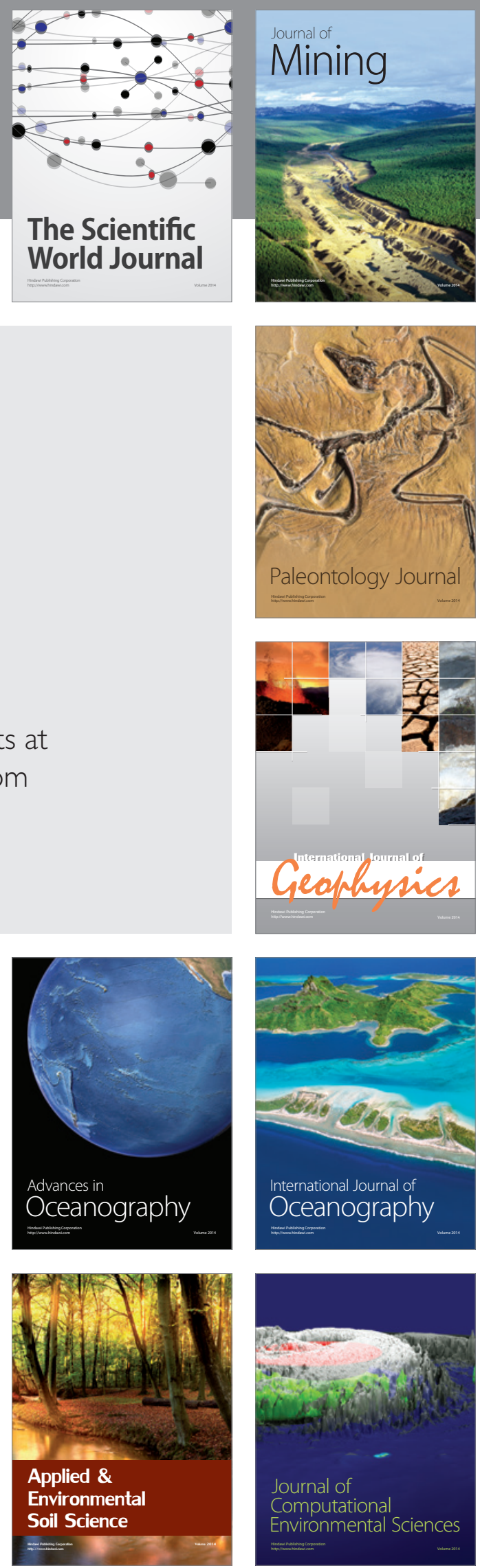